\title{
2016-os Éves Jelentés a kábítószerhelyzetről - rövid összefoglaló
}

\author{
2016 National Report on the state of the drugs problem - short summary
}

\author{
Szerzők: Nyírády Adrienn $\triangle$ \\ Nemzeti Egészségfejlesztési Intézet
}

Beküldve: 2016.10.22.

Kulcsszavak: magyarországi kábítószer-helyzet, epidemiológia, egészségügyi következmények, válaszlépések

Keywords: drugs problem in Hungary, epidemiology, health consequences, responses

\begin{abstract}
Megjelent a Nemzeti Drog Fókuszpont 2016-os Éves Jelentése, amely megújult formában mutatja be a magyarországi kábítószer-helyzetet, és benne a legfrissebb, 2015. évi adatokat. Az Éves Jelentés számot ad a kábítószer-probléma alakulásával és a válaszlépésekkel kapcsolatos legfontosabb fejleményekről, így a szerhasználati mintázatokban bekövetkezett változásokról és a kezelésbe kerülőkről; a fertőző betegségek és a halálozás alakulásáról; valamint a legújabb kábítószerpiaci lefoglalási és bűnözési statisztikákról.
\end{abstract}

\section{A FŐBB KÁBÍTÓSZEREK ÉS RELATÍV FONTOSSÁ- GUK}

A kutatási adatok alapján a 18-64 éves népességben minden tizedik (9,9\%), a 18-34 éves fiatal felnőtt populációban csaknem minden ötödik személy $(17,7 \%)$ fogyasztott az élete során valamilyen tiltott drogot. A felnőtt népességben a legtöbben marihuánát vagy hasist próbáltak (7,4\%), illetve közel fele ekkora, de a többi szerhez képest kimagasló az ecstasy (4\%) életprevalencia értéke. A legnépszerúbb szereket - azoktól jelentősen elmaradva - követik a szintetikus kannabinoidok (1,9\%), az amfeta min (1,7\%) és a designer stimulánsok (1,3\%). A fiatal felnőtt népesség szerpreferencia sorrendje megegyezik a felnőtt lakosságéval. [1. ábra]

Az iskoláskorúak körében az életprevalencia értékek alapján a legelterjedtebb kábítószer 2015-ben (is) a marihuána volt a 9-10. évfolyamon. Az ezt követő drogok sorra legális, vagy részben legális szerek. A második helyen új pszichoaktív szer áll, a 2015-ben először kérdezett szintetikus kannabinoidok szercsoport, majd az orvosi javaslat nélkül szedett nyugtatók/altatók, ezek alkohollal történő együttes fogyasztása következik. A szintén először kérdezett, hangulatjavító szándékkal bevett fájdalomcsillapítók is hasonlóan népszerűek a tanulók körében. Hatodik helyen a szerves oldószerek belélegzése szerepel.

A következő kábítószer az amfetamin, amely így a hetedik helyre került. Hasonlóan elterjedt még az ecstasy, a kokain és az LSD fogyasztása. A többi kérdezett szer életprevalencia értéke $2 \%$ körüli. A designer drogok másik nagy csoportjának, a szintetikus katinonoknak a fogyasztása kevéssé elterjedt a középiskolások körében. [2. ábra] 
1. ábra: A szerenkénti életprevalencia értékek a 18-64 éves, és a 18-34 éves populációban, 2015-ben (\%)

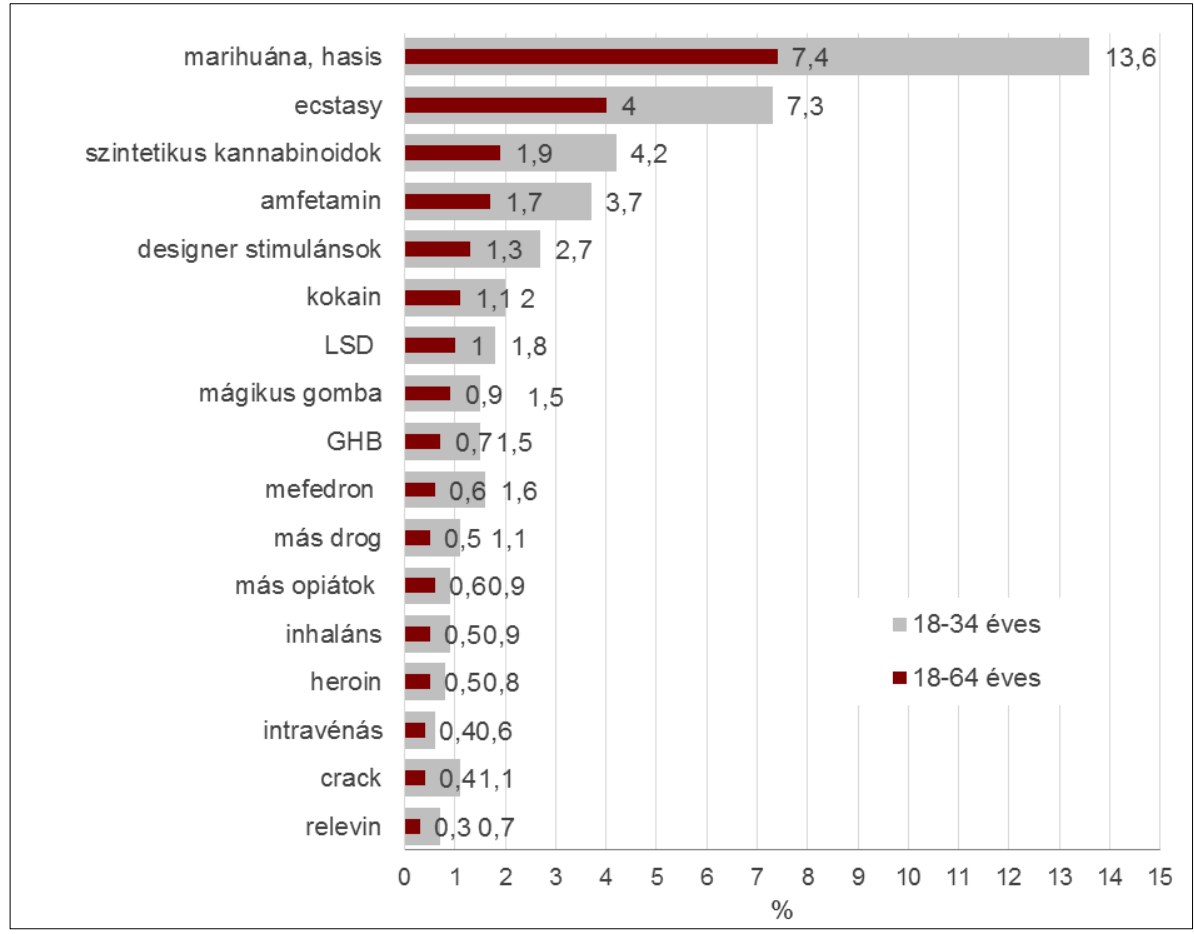

Forrás: Paksi et al. 2015, Nemzeti Drog Fókuszpont - Éves Jelentés 2016

2. ábra: Szerenkénti életprevalencia értékek a 9-10. évfolyamon tanuló diákok körében 2015-ben (\%)

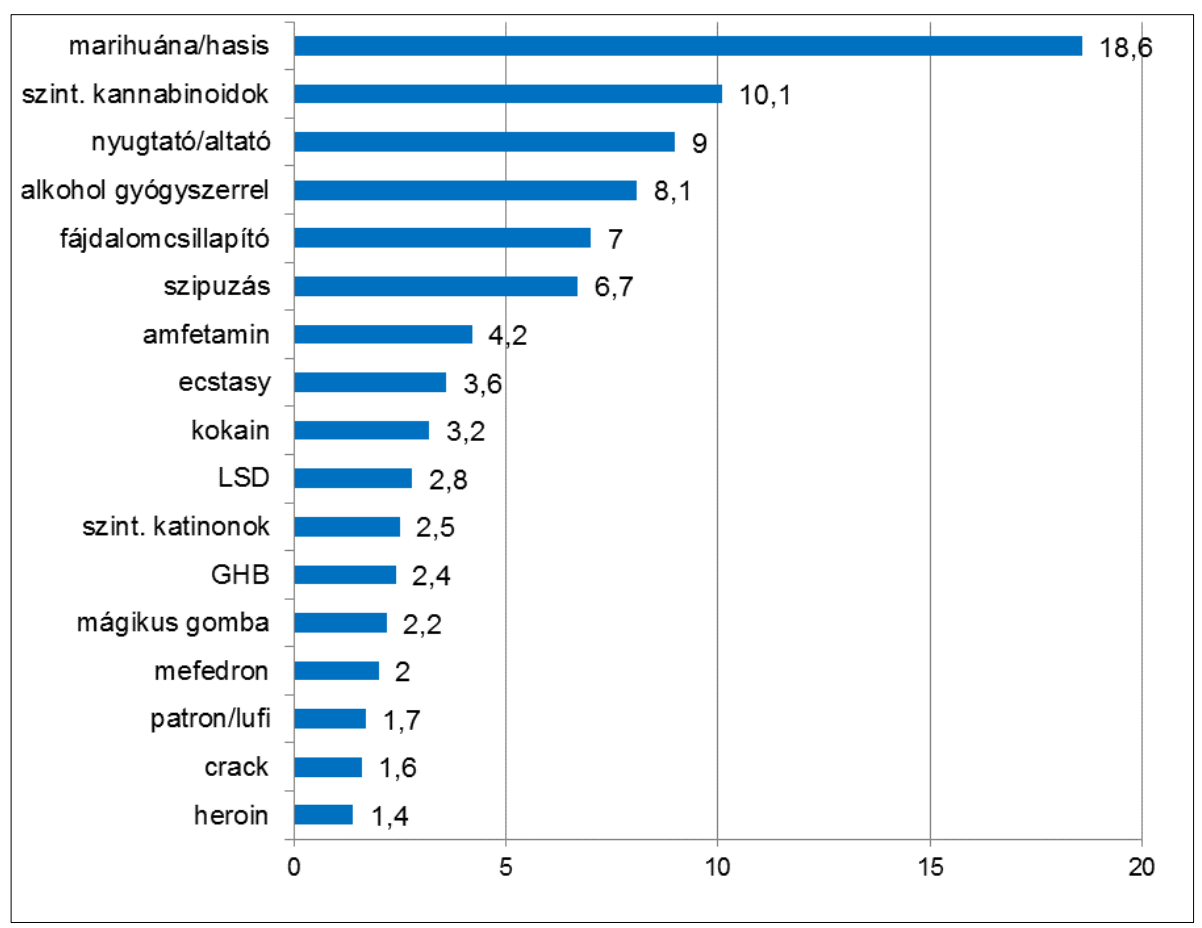

Forrás: Elekes 2016, Nemzeti Drog Fókuszpont - Éves Jelentés 2016 


\section{PREVENCIÓ}

A prevenciós programok feltárását célzó országos adatgyűjtés 2013-2015 között működően 253 szenvedélymagatartások megelőzésével (is) foglalkozó szervezetet azonosított, s közülük aktuálisan 194 szervezet van jelen a prevenciós színtéren saját, programszerü - vagyis az alkalmazott célok és módszerek tekintetében egy-egy célcsoportban homogén - prevenciós programmal. A szolgáltatók harmada Közép-Magyarországon (Budapesten és Pest megyében) található, az ország többi részében megyénként átlagosan 7-8 van jelen. A prevenciós szervezetek többsége (85\%) nem főtevékenységként végzi a prevenciós munkát, hanem zömében ellátási, egyéb segítő, vagy kisebb mértékben oktatási/nevelési tevékenységük részeként. A szervezetek döntő többsége (70\%) nonprofit szervezet. Viszonylag jelentős arányban (24\%) vannak az önkormányzatok és költségvetési szervezetek. A for-profit szféra szerepvállalása összesen $6 \%$. A szervezetek leggyakrabban egy, átlagosan 1,8, összesen 139 prevenciós programot vagy szolgáltatást múködtetnek, melyek közül 115 intervencióról rendelkezünk részletesebb információval. A beavatkozások leginkább a 14-18 éves fiatalokat célozzák meg. A tartalmi vonatkozásokat vizsgálva megállapítható, hogy a programok/szolgáltatások többsége közvetlenül az előbb említett, 14-18 éves végső célpopulációra irányul, emellett megjelentek a pedagógusok által végzett beavatkozások és a pedagógus-továbbképző szerfogyasztás-megelőzési programok is, korszerúbb lett a célrendszer, azaz a komplex egészségfejlesztés érvényesül, és több órában/alkalommal találkoznak a szolgáltatók a diákokkal, mint korábban. Ugyanakkor az új pszichoaktív szerek Magyarországon megfigyelhető terjedésére nem születtek érdemi válaszok a prevenciós szolgáltatók részéről.

\section{KEZELÉS-ELLÁTÁS}

A 2015-ben a TDI' adatgyűjtési rendszerbe jelentő 79 szolgáltató összesen 4308 kezelésbe lépőről számolt be. Az összes kliens 90,5\%-a (3 900 fő) kezdett kezelést specializált járóbeteg ellátónál, alacsonyküszöbű szolgáltatónál vagy általános/mentális egészségügyi szolgáltatónál. Járóbeteg ellátás keretei között 2780 fő lépett elterelés miatt kezelésbe. Fekvőbeteg ellátás keretében az összes kliens 9,5\%-a (408 fő) kezdett kezelést 2015 folyamán, közülük elterelésben vett részt 8 fö. Az összes klienst tekintve $64,9 \%$ volt az elterelés útján kezelésben részesülő aránya. Az addiktológiai kezelések okaként leggyakrabban megnevezett szer Magyarországon a kannabisz, használói aránya különösen magas a büntetőeljárás alternatívájaként kezelésbe lépők körében. A második legjellemzőbb, kezelést indokló szerhasználati probléma a stimulánsfogyasztás. [3. ábra és 4. ábra]

Megnövekedett a designer szerek - kannabinoidok és stimulánsok - miatti kezelési igények száma. A kezelési adatok szerint ezen szerek használata intenzívebb, és a használók életkora is lefelé tolódott. A kezelési adatok mellett több kutatás is igazolta a designer szerek miatt hamarabb kialakuló kezelési igényt. Az addiktológiai problémák mellett a sürgősségi/klinikai toxikológiai és a pszichiátriai kezelési igények száma is növekedést mutatott az elmúlt években a beszámolók szerint.

A szolgáltatók jelentése szerint 2015-ben összesen 669 kliens részesült szubsztitúciós kezelésben az év során, ez szakértői becslések szerint az összes eset $80 \%$-át fedi le. A metadon vagy buprenorfin/ naloxon kezelésben részesülők 95,2\%-a (637fő) fenntartó kezelés céljából, 4,8\%-a (32 fő) detoxikálás céljából kapott szubsztitúciós szert. A fenntartó kezelések 79,7\%-ában metadont használtak, ez az arány szinte azonos az előző években mérttel.

\footnotetext{
i TDI= Treatment Demand Indicator - Kezelési Igény Indikátor

ii Jogszabályban meghatározott feltételek fennállása esetén a kábítószerekkel kapcsolatos búncselekmények esetében az elkövetőnek lehetősége van kezelési/megelőző beavatkozásokban való részvétellel a büntetőeljárást elkerülni.
} 
3. ábra: A kezelési igény elsődleges szer szerinti megoszlása (2015; \%; N=4308)

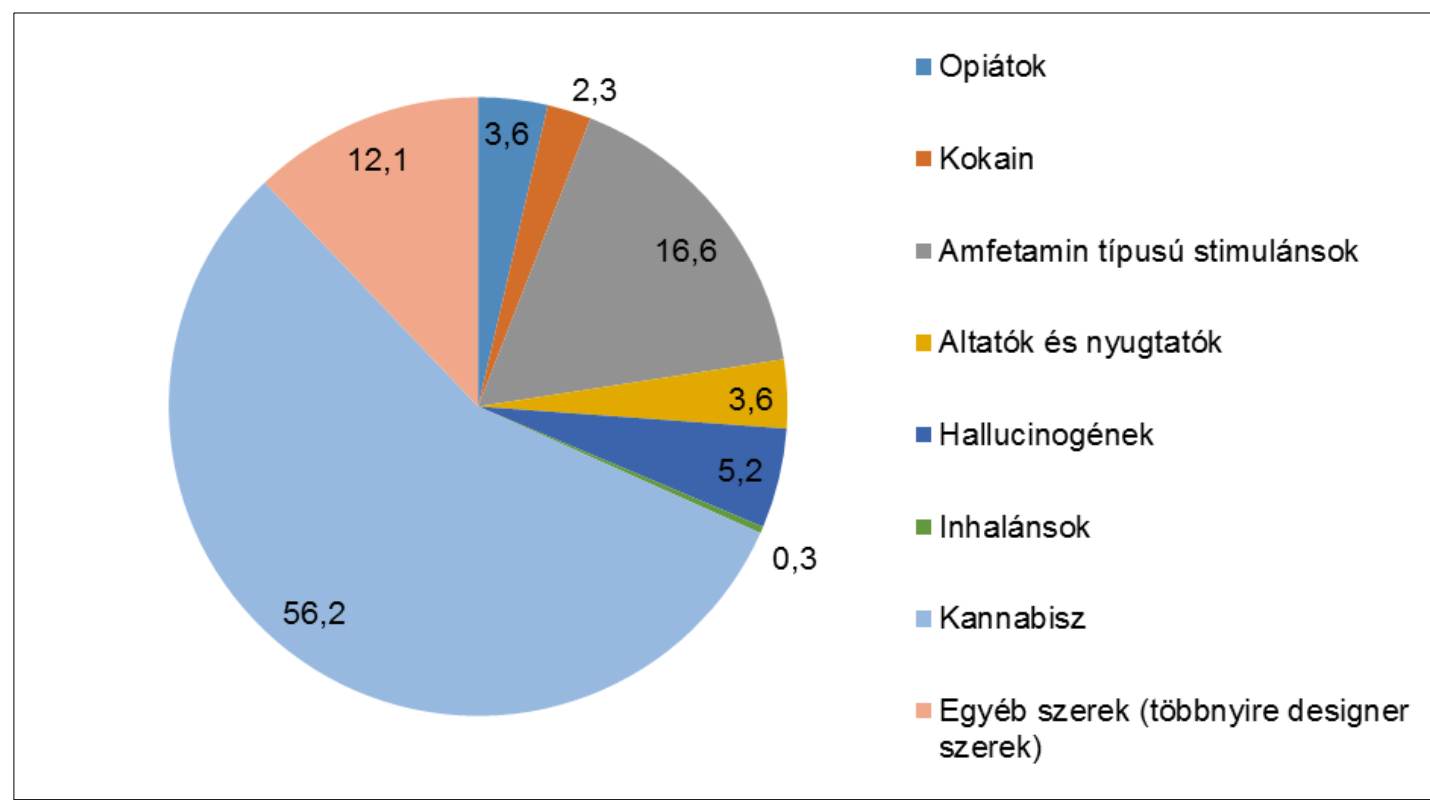

Forrás: TDI adatgyűjtés 2016, Nemzeti Drog Fókuszpont - Éves Jelentés 2016

4. ábra: A kezelést kezdök szertípus szerinti megoszlása az eltereltek és nem eltereltek körében 2015-ben (fö) $(N$ (elterelt) $=2788 ; N$ (nem elterelt) $=1510)$

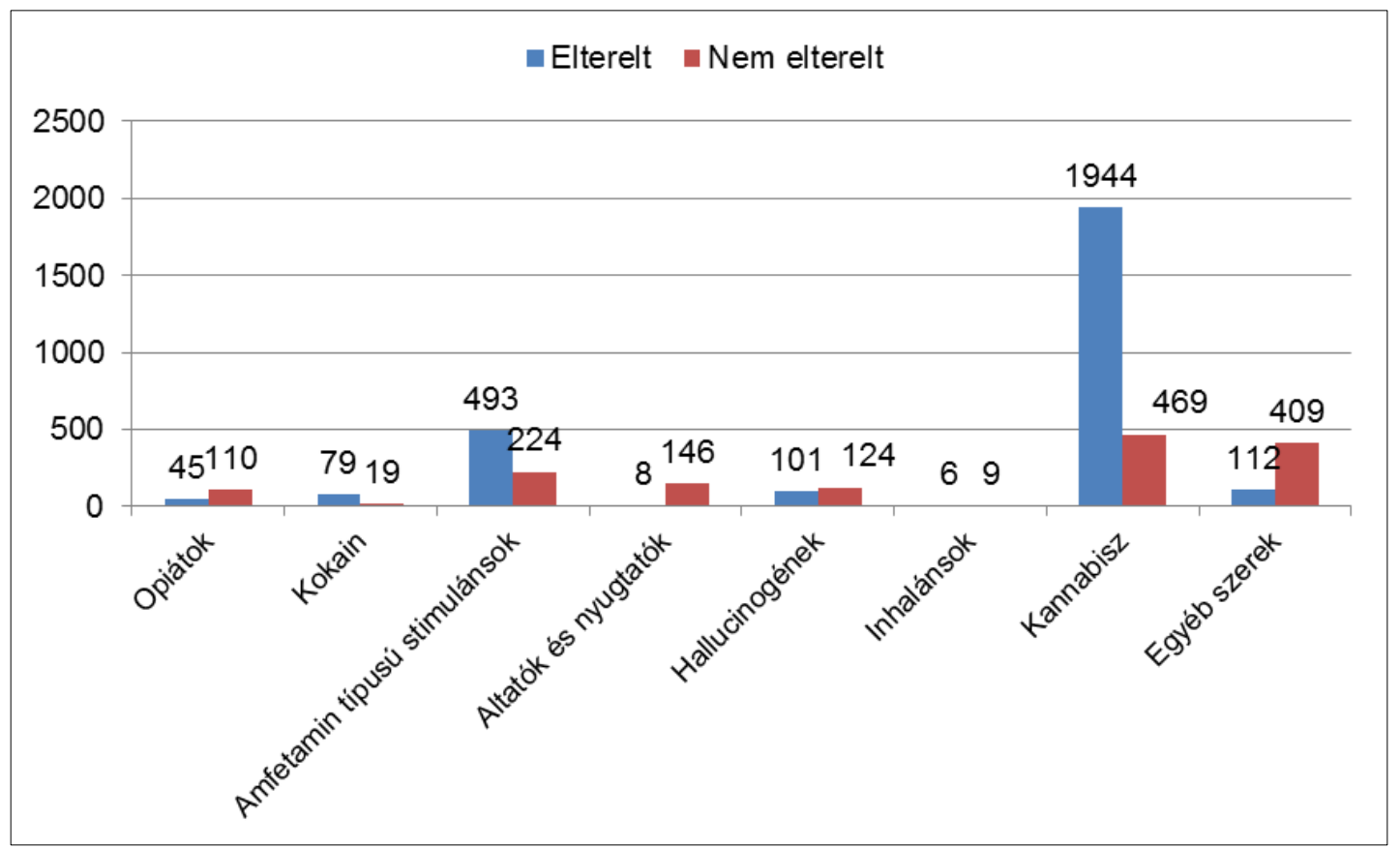

Forrás: TDI adatgyűjtés 2016, Nemzeti Drog Fókuszpont - Éves Jelentés 2016 


\section{EGÉSZSÉGÜGYI KÖVETKEZMÉNYEK}

A tû́csere adatok alapján az új pszichoaktív szerek (ÚPSZ) 2010-tôl kezdődő térnyerése teljesen átalakította a megelőző évekre jellemző szerhasználati struktúrát: míg 2009-ben a kliensek kevesebb mint 4\%-a injektált elsődlegesen valamilyen új pszichoaktív szert, addig 2015-ben már a tǔcsere szolgáltatást igénybevevők $80 \%$-a vallotta azt elsődlegesen injektált szerének. Az amfetamin és heroin injektálás térvesztése tovább folytatódott 2015-ben. Az egyéb opiátok (elsősorban a metadon) intravénás használata 7-9\% között mozgott az elmúlt években. A sti- mulánsok tekintetében, az új pszichoaktív szerek, azaz a designer stimulánsok 2013-tól már az amfetamint is kiszorították: míg 2009-2012 között 40\% körül volt az elsődlegesen amfetamint injektálók aránya, 2015-re ez 10\%-ra csökkent. [5. ábra]

Az új pszichoaktív szereket injektálók körében 2015ben is a „pentakristály" volt a leggyakrabban injektált elsődleges szer (65\%). Ezt követte a - 2014-ben szintén második helyet betöltő - „zene” (31\%). A többi ÚPSZ, mint például az MDPV, a mefedron vagy a benzon előfordulási gyakorisága $4 \%$ alatti volt az elsődlegesen ÚPSZ-et injektálók körében.

5. ábra: A tücsere programban részt vevő kliensek elsődlegesen injektált szer szerinti megoszlása 2009-2015 között (\%)

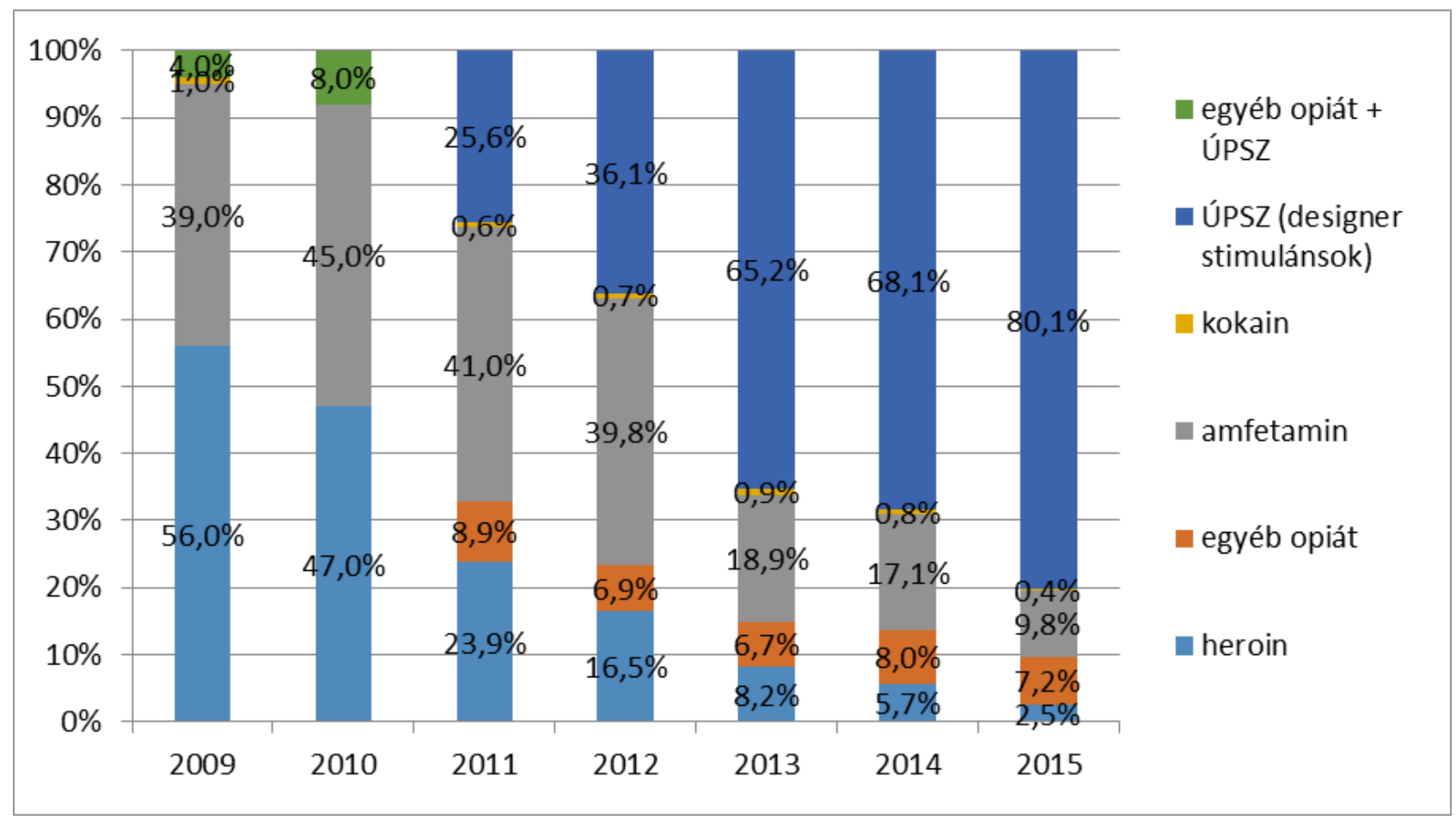

Forrás: Tarján 2016b, Nemzeti Drog Fókuszpont - Éves Jelentés 2016

Az országos HIV/HBV/HCViii prevalencia vizsgálatok során 2015-ben 1 fő esetében diagnosztizáltak HIVfertőzést. A HBV fertőzöttek aránya 2,2\% volt, míg a HCV prevalencia 49,7\%-os volt. 2015-ben vidéken szignifikánsan nőtt a HCV fertőzöttek aránya (40,5\%) míg Budapesten nem változott szignifikán- san $(55,7 \%)$, azonban a budapesti adatok trendelemzésére csak korlátozottan van lehetőség. 2015ben az elmúlt 4 hétben is injektáló, aktív szerhasználók körében az új pszichoaktív szereket injektálók alkották a legnagyobb csoportot, körükben a HCV prevalenciája $78,7 \%$ volt.

\footnotetext{
iii HIV= Human Immundeficiency Virus, HBV=Hepatitis B vírus, $\mathrm{HCV}=$ Hepatitis $\mathrm{C}$ vírus
} 
A 2015-es országos HIV/HBV/HCV prevalencia vizsgálat alapján, az aktív szerhasználók 38,9\%-a osztotta meg a fecskendőjét a vizsgálatot megelőző 4 hétben, míg a bármilyen injektáló segédeszköz megosztásának előfordulási gyakorisága a vizsgálatot megelőző 4 hétben 55,7\% volt. Ha szertípus szerinti bontásban vizsgáljuk az eszközmegosztást, elmondható, hogy a prevalencia értékek az új pszichoaktív szereket injektálók esetében a legmagasabbak (fecskendő-megosztás: 48,5\%, injektáló eszközök megosztása: 67,1\%).

2015-ben 25 kábítószer-használattal közvetlenül összefüggő túladagolásos és 40 közvetetten összefüggő halálesetet jelentettek a speciális halálozási regiszterbe. A 25 halálesetből 4 esetben volt nő az elhunyt. A túladagolásos esetek körében a férfiak átlagéletkora 34 év, a nőké 29,5 év, együttesen pedig 33,2 év volt. Az opiátokhoz és a metadonhoz köthető halálesetekben az átlagéletkor 34,8 év volt. A 25 halálesetből 10 (40\%) - közöttük három női eset - Budapesten történt, megyeszékhelyen egy, kisvárosban két, községben hat haláleset fordult elő. Négy esetben volt az elhunyt hajléktalan, két esetben pedig külföldi személy.

\section{VÁLASZLÉPÉSEK}

2015-ben 30 szervezet múködtetett tűcsere programot összesen 21 városban, amely az ország 14 megyéjét és 7 régióját jelenti. [6. ábra] 2015-ben az országban 26 állandó telephelyú program múködött ez volt a legjellemzőbb forma. 13 szervezetnél végeztek utcai megkereső munkát, 3 szervezet múködtetett mobil túcsere programot, és 4 helyen tudtak igénybe venni tû-automatát az injektáló szerhasználók. 9 szervezet üzemeltetett kéttípusú programot, ez legtöbb esetben az állandó telephelyú programhoz kapcsolódó, utcai megkereső munka volt, ami egyben a legjellemzőbb kombinációja a különböző típusú tevékenységeknek.

2015-ben a két legnagyobb budapesti túcsere program 2014 második felében történő bezárásának hatása mérhető volt a forgalmi adatokban. A kiosztott fecskendők száma 59\%-kal (188 696 darabra), míg a hozott és gyűjtött fecskendők száma 49\%-kal (150 565 darabra) csökkent az előző évhez képest. [7. ábra] A kliensek száma 23\%-kal (3 436 före), míg a kontaktok száma 41\%-kal esett vissza (24 368 alkalomra). Egy intravénás szerhasználóra 33 fecskendő jutott a tárgyévben.

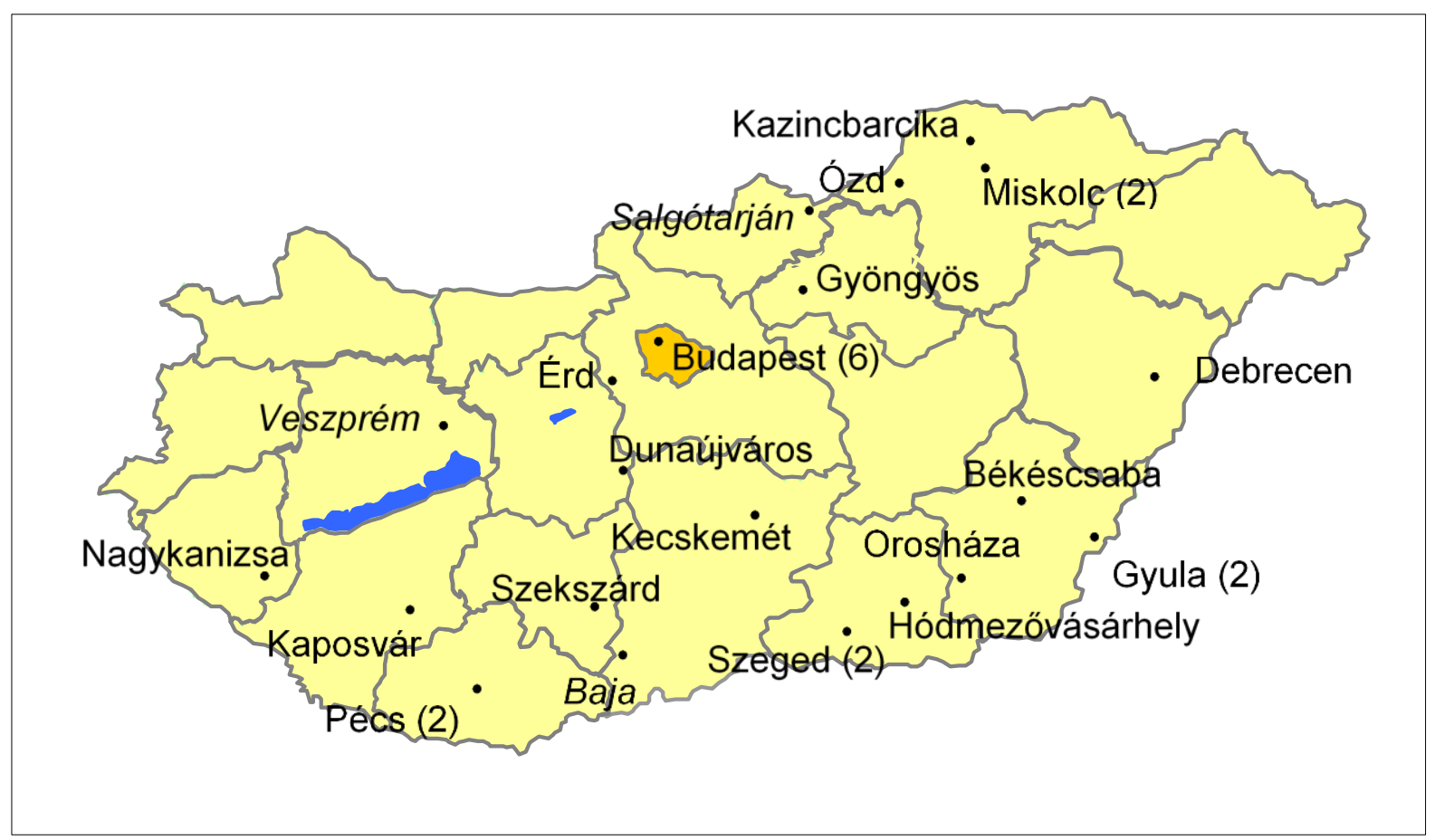

Forrás: Tarján 2016b, Nemzeti Drog Fókuszpont - Éves Jelentés 2016 
7. ábra: A tücsere programok fecskendőforgalmi adatai, 2011-2015 között (db)

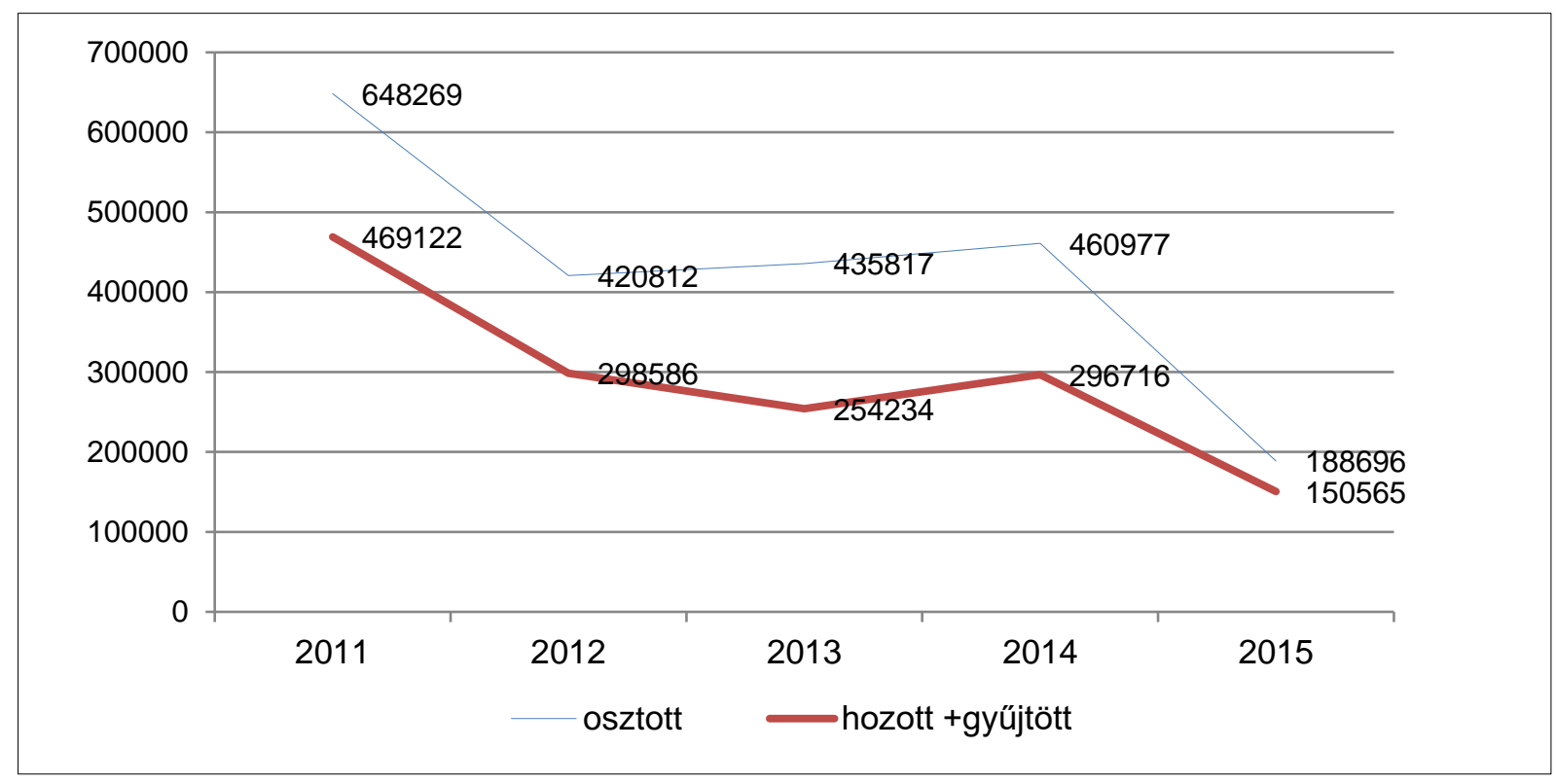

Forrás: Tarján 2016b, Nemzeti Drog Fókuszpont - Éves Jelentés 2016

\section{KÁBÍTÓSZERPIAC ÉS KÁBÍTÓSZER-BŰNÖZÉS}

A Búnügyi Szakértői- és Kutatóintézet lefoglalási adatai alapján a nagytételben lefoglalt marihuána mennyisége 2012-ben jelentősen megugrott, azóta viszont folyamatosan csökken. A hasis lefoglalások száma azonban az előző évekhez hasonlóan 2015ben is tovább emelkedett. A heroin esetében elmondható, hogy a lefoglalások számában növekedés tapasztalható 2014-hez képest, azonban lefoglalta mennyiség jelentősen csökkent. Az amfetamin lefoglalások száma - a kis tételü, 10 gramm alatti lefoglalások trendjéből adódóan - szintén enyhe emelkedést mutat és ez a trend jellemző az MDMA tartalmú tablettákra is. Az LSD lefoglalások száma a fenti anyagokhoz képest nem jelentős, ezek az esetek jellemzően a nagy nemzetközi érdeklődés mellett zajló nyári zenei fesztiválokhoz köthetők. Az új pszichoaktív anyagok 2010-2014 folyamán teljesen átrendezték a magyar kábítószerpiacot. A lefoglalási adatok alapján 2013-ra az új szerek piaci részesedése meghaladta a „klasszikus” - az ENSZ Kábítószer Egyezményeinek valamely jegyzékén szereplő - szerek piacát Magyarországon. 2014-ben a „designer drogok" már a lefoglalt anyagok 60\%-át tették ki. 2015-ben azonban a trend megváltozott, az új pszichoaktív anyagok lefoglalásai a klasszikus kábítószer-lefoglalásokhoz közeli szintre estek vissza.

Magyarországon 2015-ben 24 új pszichoaktív szert azonosítottak. A kannabinoidok csoportjára a gyors és állandó változás a jellemző, mintegy félévente a szerek új csoportja jelent meg, legelőször a JWH-k, legújabban a FUBINACA, PINACA és CHMINACA csoportba tartozó szerek terjedtek el. Stimulánsok közül néhány szer, ha viszonylagosan is, de dominánsabban volt jelen a piacon: 2010-ben a mefedron, 2011-ben az MDPV, azt követően 2012-től pedig a pentedron. 2014-ben a pentedron mellett az $\alpha$-PVP ért el említésre méltó részesedést a lefoglalási adatok szerint, majd 2015-ben az $\alpha$-PHP elterjedése volt jellemző.

2015-ben 6625 kábítószerhez vagy új pszichoaktív anyaghoz köthető bűncselekmény miatt indított nyomozás zárult le. A kábítószerhez köthető bűncselekmények az összes hazánkban regisztrált búncselekmény 2,4\%-át tették ki. 
A 2015-ben regisztrált búncselekmények felét (52,1\%, 3301 eset) kannabisszal követték el, 28,7\%át (1 811 eset) sti-mulánsokkal, 6,8\%-át új pszichoaktív anyagokkal (432 eset). [8. ábra] A stimulánsokkal elkövetett esetek között az elkövetés tárgyaként leggyakrabban előforduló kábítószerek az amfetamin (83,4\%), az MDMA (ecstasy) (7,9\%) és a metamfetamin $(5,4 \%)$ voltak. Az elkövetés tárgyaként kokain a búncselekmények 3,5\%-ában, opiátok 2,6\%-ban, hallucinogének 1,3\%-ban, egyéb kábító- szerek 4,3\%-ban kerültek rögzítésre.

Az új pszichoaktív anyagokkal való (kereskedői típusú) visszaélés 2012 márciusa óta von maga után büntetőjogi felelősségre vonást, az ezekkel a szerekkel elkövetett visszaélések évről évre egyre növekvő hányadát teszik ki a kábítószer-búncselekményeknek. 2015-ben az új pszichoaktív anyagok között a legnagyobb arányban katinon származékok (33,6\%), szintetikus kannabinoidok (22,5\%) és fenetilaminok (17,8\%) szerepeltek az elkövetés tárgyaként.

8. ábra: Ismertté vált kábítószer-büncselekmények megoszlása elkövetői magatartások és szertípusok szerint, 2015

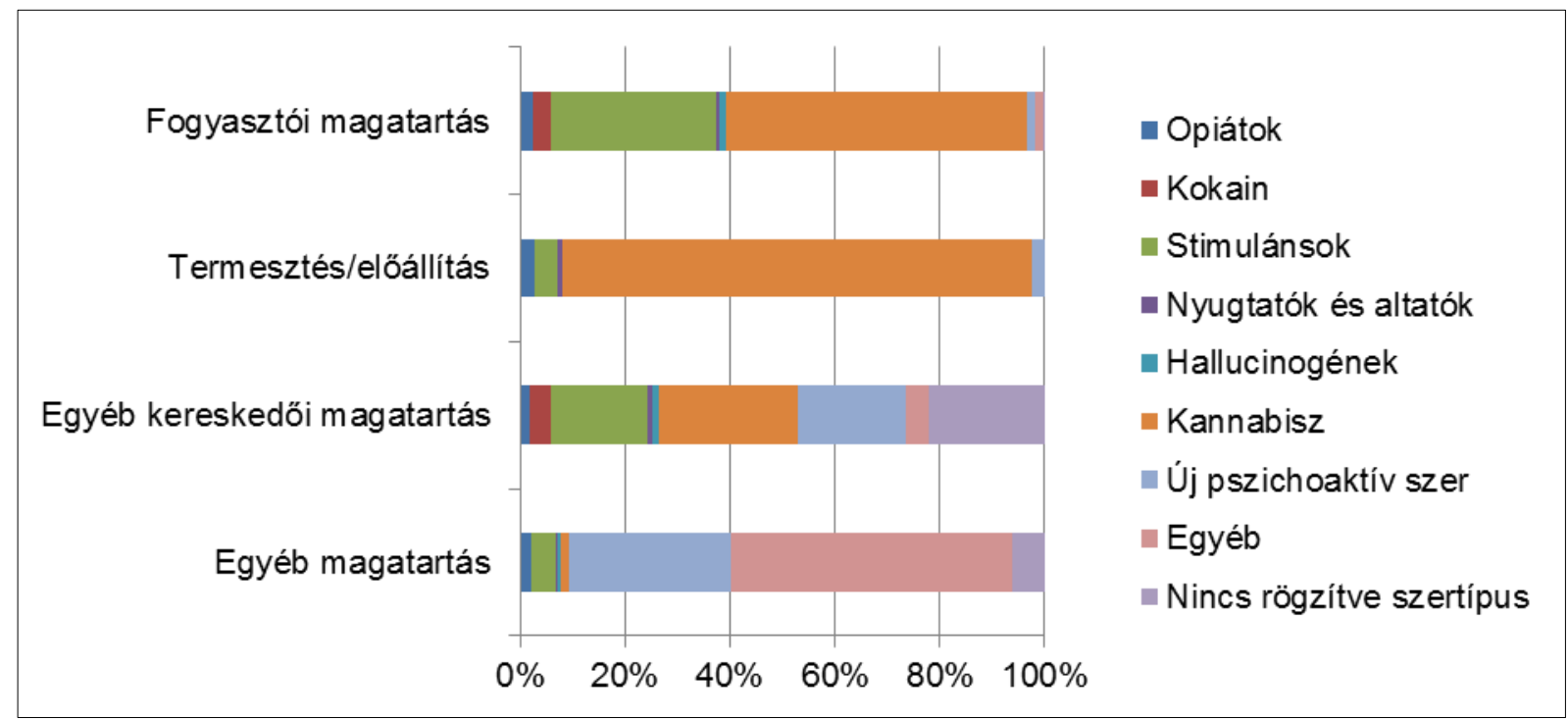

Forrás: ENYÜBSiv 2016, Nemzeti Drog Fókuszpont - Éves Jelentés 2016

2015-ben a 6625 regisztrált kábítószer-búncselekményhez kötődően 6043 elkövetőt regisztrált a bűnügyi statisztika. Az elkövetők $90 \%$-a férfi, 10\%-a nő volt. Az elkövetők életkor szerinti megoszlását tekintve 11\%-uk 18 év alatti, 35\%-uk 19 és 24 év közötti, 26\%-uk 25 és 30 év közötti fiatal volt, összességében tehát a kábítószer-búncselekményt elkövetők 72\%-a a 30 évesnél fiatalabb korosztályból került ki. Összehasonlítva az összes bűnelkövető életkori megoszlásával, a kábítószer-búncselekménye- ket elkövetők az egyéb búncselekmények elkövetőinél jóval fiatalabbak: az összes bűnelkövető között a 30 év alattiak aránya 44\%-ot tett ki.

A kábítószer-bűncselekmények több mint harmadát a fövárosban (32,7\%), vagy Pest megyében $(6,2 \%)$ regisztrálták 2015-ben. Sorrendben a legnagyobb számú kábítószer-bűncselekményt a főváros és Pest megye után Borsod-Abaúj-Zemplén, Győr-MosonSopron és Fejér megyékben regisztrálták. [9. ábra]

\footnotetext{
iv Egységes Nyomozó Hatósági és Ügyészségi Búnügyi Statisztikai Rendszer
} 
9. ábra: A kábítószerrel elkövetett büncselekmények száma megyék szerinti bontásban 2015-ben

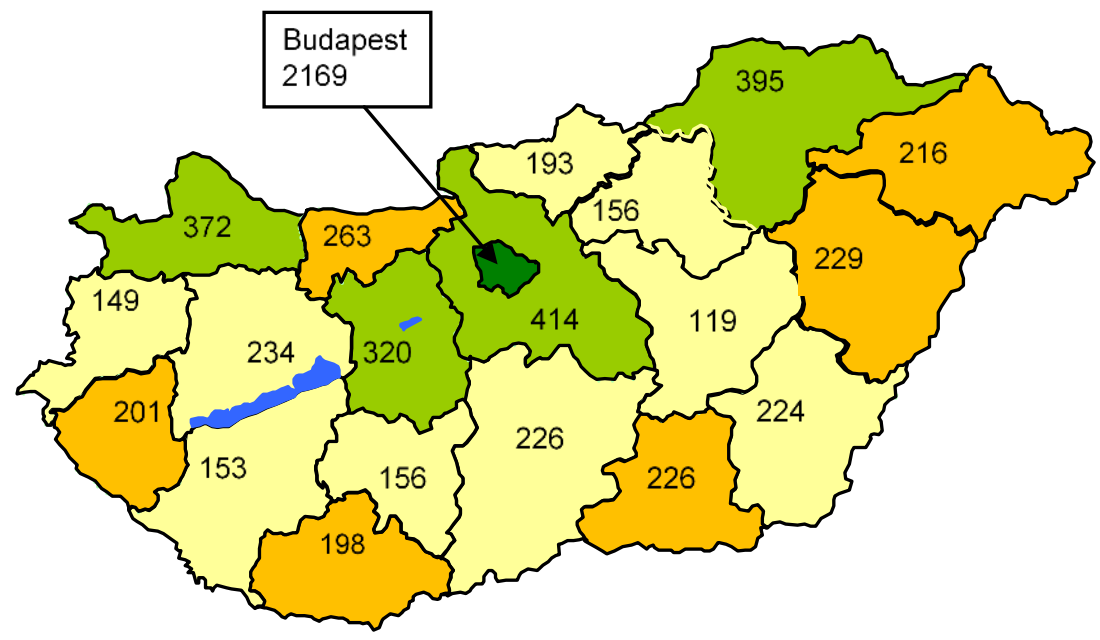

1000 felett

$300-200$

200 alatt

Forrás: ENYÜBS 2015, Nemzeti Drog Fókuszpont - Éves Jelentés 2016 